\title{
Gamete concentrations and timing and success of fertilization in a rocky shore seaweed
}

\author{
Mary-Lynn Berndt ${ }^{1, *}$, James A. Callow ${ }^{2}$, Susan H. Brawley ${ }^{1, * *}$ \\ ${ }^{1}$ School of Marine Sciences, University of Maine, 5722 Deering Hall, Orono, Maine 04469-5722, USA \\ ${ }^{2}$ School of Biosciences, University of Birmingham, Edgbaston, Birmingham B15 2TT, United Kingdom
}

\begin{abstract}
Whether sperm limitation or sperm competition occurs during fertilization in the sea has drawn increasing attention because of its importance in understanding population structure and recruitment. Inferences have been based upon both artificial and natural studies of in situ fertilization success, because natural gamete concentrations have been difficult to measure. Here, gamete concentrations and the timing of fertilization were examined during the tidal cycle in the fucoid alga Fucus vesiculosus L. on the Maine coast at Pemaquid Point and in the Narraguagus River estuary. Gamete concentrations were assessed by collecting samples from the water column throughout the tidal cycle; sperm were identified by indirect immunofluorescence using a $F$. vesiculosus-selective monoclonal antibody raised against sperm from a Maine population of this species. Eggs were detected visually, and fertilization was assessed by the presence and position of a sperm pronucleus within the egg. Gamete release occurred only on calmer days (Pemaquid Point) or calmer periods of the tidal cycle (Narraguagus estuary), and sperm:egg ratios near the time of fertilization ranged from 10:1 to $70: 1$. Fertilization success was $100 \%$ in both locations. Nearly all eggs were fertilized within a $1 \mathrm{~h}$ interval of the 6 to $7 \mathrm{~h}$ long high tide, 2 to $3 \mathrm{~h}$ after algae were covered by seawater. Gamete release occurred at low tide after a prolonged period ( $3 \mathrm{wk}$ ) of stormy weather that inhibited gamete release during high tide; this has implications for dispersal and interspecific hybridization. Archival environmental data from the US National Oceanic and Atmospheric Administration (NOAA, 1982 to 2000) were used to predict the frequency of successful reproduction during high tide and the potential for gamete release at low tide. These studies demonstrate that sperm are not limiting to fertilization in F. vesiculosus.
\end{abstract}

KEY WORDS: Fertilization - Fucoids · Gametes · Hybridization - Intertidal zone - New England · Reproductive ecology $\cdot$ Sperm competition and limitation

\section{INTRODUCTION}

Fertilization directly affects recruitment; hence, population models of marine species and an understanding of reproductive traits within and among species are dependent upon predictions of fertilization success. Recently there has been particular examination of whether sperm limitation or sperm competition occurs

\footnotetext{
*Present address: Station Biologique de Roscoff, Place Georges Teissier, 29680 Roscoff, France

${ }^{* *}$ Corresponding author. E-mail: brawley@maine.edu
}

in marine species with external fertilization (e.g., reviews by Levitan \& Petersen 1995, Yund 2000). The hydrodynamic conditions at gamete release are widely regarded as determining whether sperm limitation occurs (e.g., Pennington 1985, Denny \& Shibata 1989, Petersen 1991, Levitan et al. 1992, Oliver \& Babcock 1992, Serrão et al. 1996). Most marine species use multiple cues including seasonality and lunar or semilunar rhythms (e.g., Giese \& Kanatani 1987, Brawley \& Johnson 1992) to achieve synchronous maturation of sperm and eggs, but less is known about the factors that regulate gamete release on a fine temporal scale. Such fine-scale synchrony of sperm and egg release is criti-

(C) Inter-Research $2002 \cdot$ www.int-res.com 
cal to fertilization success, as demonstrated by low success when animals spawn alone, spatially or temporally (e.g., Babcock \& Mundy 1992, Babcock et al. 1994), or where adults of one sex are rarer than the other (e.g., Lasker et al. 1996). Recent work on fucoid algae has demonstrated that hydrodynamic conditions are perceived by adults and that water motion becomes the proximate, dominant determinant in whether ripe gametes are released (Serrão et al. 1996, Pearson et al. 1998). Remarkably, a change from calm to turbulent conditions on a time scale of a few hours will inhibit gamete release (Serrão et al. 1996, Pearson \& Brawley 1998).

The finding that natural fertilization success in fucoid algae is close to $100 \%$ (Brawley 1992, Pearson \& Brawley 1996, Serrão et al. 1996) is hypothesized to be related to the sensitivity of adults to water motion, because gamete release under calmer conditions should prevent sperm dilution. Predictions of low fertilization success in spawning invertebrates (e.g., Pennington 1985, Levitan et al. 1992) were based upon field experiments in which artificial spawning of adults was part of the experimental design. This would bypass any natural responses that prevent gamete release by adults under unfavorable conditions for fertilization. Although data on natural fertilization success are still sparse, fertilization success in an array of other algae, vertebrates, and invertebrates with external fertilization ranges from ca 80 to $100 \%$ on most days (e.g., Petersen 1991, Babcock \& Mundy 1992, Oliver \& Babcock 1992, Petersen et al. 1992, Sewell \& Levitan 1992, Babcock et al. 1994, Marconato \& Shapiro 1996, Grant et al. 1998, Kiflawi et al. 1998, Engel et al. 1999). Lower fertilization success is found, at least at times, in several other algae and invertebrates (Babcock et al. 1992, Kaczmarska \& Dowe 1997, Lasker et al. 1996, Coma \& Lasker 1997).

Sperm competition seems more likely than sperm limitation when fertilization approaches $100 \%$, but direct data on natural sperm:egg ratios and concentrations are required to address this question. We report such data here for the dioecious seaweed Fucus vesiculosus, one of the most abundant species in north Atlantic intertidal zones. Examination of gamete concentrations during the tidal cycle also permitted us to determine how soon gamete release and fertilization occur after algae are rehydrated by the incoming tide, which has been a controversial subject (Fritsch 1945, Brawley et al. 1999).

\section{MATERIALS AND METHODS}

Monoclonal antibodies. Murine monoclonal antibodies with selectivity for Fucus vesiculosus sperm were produced using the general methods of Jones et al. (1988). The sperm preparation injected into the mouse was prepared from $F$. vesiculosus sperm collected from algae at Schoodic Point (ME, USA). The sperm were fixed in $0.2 \%$ glutaraldehyde and $2 \%$ paraformaldehyde in seawater, $\mathrm{pH} 7.8$, for $1 \mathrm{~h}$; pelleted with a table top centrifuge $\left(4^{\circ} \mathrm{C}\right)$ and washed $3 \times$ with seawater to remove fixative; and kept under liquid nitrogen until injected intra-peritoneally (IP) as a whole sperm preparation into an 8 wk-old balb-c mouse. The same antigen was injected IP 5 wk later and intravenously after 1 more week. The spleen was removed $4 \mathrm{~d}$ later, and fusions made between immune spleen cells and NSO-myeloma cells as described by Galfre \& Milstein (1981). Tissue culture supernatants of the resulting hybridomas were screened with ELISA and indirect immunofluorescence as described by Jones et al. (1988). The ELISA used fixed sperm of $F$. vesiculosus (ME, USA, and Isle of Man, British Isles) and $F$. serratus (GB) to develop monoclonal antibodies that were selective for $F$. vesiculosus. Cell lines showing selective binding to $F$. vesiculosus sperm were further screened against sperm of $F$. serratus (GB) and other fucoids from Maine (F. spiralis, F. vesiculosus, F. evanescens, Ascophyllum nodosum) by indirect immunofluorescent microscopy to select the most promising clones. On this basis, monoclonal 144.6 (S. $\mathrm{H}$. Brawley) was selected for field studies of $F$. vesiculosus because it did not bind to sperm of $A$. nodosum or $F$. evanescens, bound weakly to F. serratus and F. spiralis, and did not bind to other components of the plankton or cultures of other heterokont algae (see 'Results', Berndt 2000).

Sperm and egg quantification. Fixed field samples were concentrated to $2.5 \mathrm{ml}$ using the device described by Miller \& Scholin (1998), fitted with $1.2 \mu \mathrm{m}$ Millipore filters. Eggs in a $25 \mu \mathrm{l}$ aliquot of each concentrate were quantified with brightfield microscopy (100×). To quantify sperm, indirect immunofluorescence was used to distinguish sperm from other small flagellates. Monoclonal 144.6 was used without dilution; $10 \mu \mathrm{l}$ of the primary antibody was placed over an air-dried sample $(10 \mu \mathrm{l}$ of each concentrate per $8 \mathrm{~mm}$ diameter well using coated slides, Electron Microscopy Sciences, Ft. Washington, PA) and incubated for $30 \mathrm{~min}$ at room temperature. Slides were gently washed $3 \times$ with $100 \mathrm{mM}$ Tris-buffered saline (TBS), $\mathrm{pH} 7.5$, and incubated for $30 \mathrm{~min}$ in FITC-conjugated secondary antibody (sheep anti-mouse, Sigma Chemical Co., \#F2657; 1:60 in TBS containing 1\% nonfat dry milk). Slides were washed gently $3 \times$ with TBS and mounted for immunofluorescence using Vectashield mounting medium (Vector Laboratories, CA) to inhibit photobleaching. Sperm were quantified over the entire well using a Nikon Optiphot-2 microscope (400×) with FITC 
filters. Values were extrapolated to cells $\mathrm{l}^{-1}$ on the basis of this quantification and grouped within 30 min collection intervals to provide site values (mean $\pm \mathrm{SE}$ ). Triplicate $10 \mu \mathrm{l}$ aliquots of 10 randomly selected samples were counted to evaluate error based upon evaluation of a single $10 \mu \mathrm{l}$ aliquot; counting error was found to be $\leq 12 \%$, and analysis proceeded with single aliquots due to the large number of field samples (ca 80 $\mathrm{d}^{-1}$ ) that required screening.

Field sites and reproductive characteristics. Field studies were conducted on the western side of Pemaquid Point, ME (4350' $\left.8^{\prime \prime} \mathrm{N}, 69^{\circ} 30^{\prime} 29^{\prime \prime} \mathrm{W}\right)$, and in the Narraguagus River estuary $\left(44^{\circ} 34^{\prime} 0^{\prime \prime} \mathrm{N}\right.$, $\left.69^{\circ} 53^{\prime} 50^{\prime \prime} \mathrm{W}\right) \sim 1 \mathrm{~km}$ upstream from Milbridge, ME. The sex ratio of Fucus vesiculosus at both sites is 1:1 (Serrão et al. 1999), as verified in the present studies. One of the determinants in selection of these sites was that each had abundant $F$. vesiculosus compared to other fucoid seaweeds. At this section of Pemaquid Point, randomly placed $0.25 \mathrm{~m}^{2}$ quadrats $\left(\mathrm{n}=4 \mathrm{zone}^{-1}\right)$ found relative percent abundance of $16 \pm 8$ (SE) \% F. vesiculosus and $8 \pm 3 \%$ of $F$. spiralis in the high intertidal zone, $79 \pm 3 \% F$. vesiculosus and $19 \pm 7 \% A$. nodosum (not reproductive during the study) in the mid-intertidal zone, and $15 \pm 7 \%$ F. vesiculosus and $8 \pm$ $6 \% F$. evanescens in the lower intertidal zone (see Berndt 2000, for other site components, and Speransky et al. 2000, for a site map). The density of reproductively mature $F$. vesiculosus in the mid-intertidal zone where water samples were collected was $101 \pm 34$ adults $\mathrm{m}^{-2}(\mathrm{n}=10$ quadrats $)$. The site in the Narraguagus represents the uppermost reach of $F$. vesiculosus in the estuary. It is a rocky outcrop (ca $40 \times 170 \mathrm{~m}$ ) where F. vesiculosus is abundant (density of $115 \pm 19$ adults $\mathrm{m}^{-2}, \mathrm{n}=4$ quadrats); only rare, reproductively immature $A$. nodosum are found, and no other fucoids are present. The closest $F$. spiralis and $F$. evanescens to this site are $1 \mathrm{~km}$ away. Fucus vesiculosus is found between Milbridge and the studied site in the Narraguagus, but sand interrupts the fucoid populations in the estuary, and the next closest outcrop with fucoids is strongly dominated by $A$. nodosum (not reproductive during our study) and is about $200 \mathrm{~m}$ closer to Milbridge than the studied population.

Fucus vesiculosus releases gametes on semilunar cycles centered around full and new moons on the Maine coast (Serrão 1996). Receptacles (reproductive tissue) develop at the tips of branches and release antheridia (males), each containing 64 biflagellate sperm, or oogonia (females), each containing 8 eggs (Fritsch 1945). Sperm and eggs are released from antheridia and oogonia shortly after expulsion from the receptacle. Eggs secrete a pheromone that is a spermattractant (Müller \& Gassman 1978). There is no larval stage, and the zygote secretes wall material and attaches to surfaces 4 to $24 \mathrm{~h}$ post-fertilization (temperature dependent). Samples were collected at the Pemaquid site on 8 and 25 October 1999, 8, 9 and 24 November 1999, and 17 April 2000; samples were collected from the Narraguagus site on 1 and 2 July 2000. Estuarine algae are ripe in mid-summer to early fall, whereas open-coast algae are reproductively mature in fall to early winter and, following recovery from ice damage, for a short time in the spring (Speransky et al. 1999).

A modified pump based upon Mundy et al. (1994) was used to collect samples at Pemaquid Point and in the Narraguagus estuary. Two pumping stations were located about $40 \mathrm{~m}$ apart; each pump was a Flojet ${ }^{\mathrm{TM}}$ bilge pump (Flojet Co., CA) with flowspeed monitored by a flow meter (Model 2221-S1005, Orange Research Inc., Milford, CT) and controlled by a rheostat attached to the portable $12 \mathrm{~V}$ battery used to power the pump (Fig. 1a). Each pump was used in association with 3 collection sites, whose positions were selected along a transect line in the mid-intertidal zone with random numbers. Thus, 6 replicate areas were sampled on each day. The distance between adjacent replicates was 5 to $16 \mathrm{~m}$ (Fig. 1b). Clear, polypropylene $(1.27 \mathrm{~cm}$ i.d.) tubing (30 to $40 \mathrm{~m}$ long) was anchored to the substratum with eye bolt anchors between each vertical collection tube, which ended in a funnel $15 \mathrm{~cm}$ above the substratum in the bed, covered by $2 \times 2 \mathrm{~cm}$ plastic mesh to prevent clogging), and the collection and concentration cartridges (US Filter Inc polypropylene/styrene water filter cartridges, as \# 4422K3 from McMaster-Carr Supply Co., New Brunswick, NJ). The core of the modified filter cartridge was a $2.5 \mathrm{~cm}$ (i.d.) PVC pipe drilled to capacity with $1 \mathrm{~cm}$ (diameter) holes and wrapped $2 \times$ with $1 \mu \mathrm{m}$ Nitex (Small Parts Co., Miami Lakes, FL), which was sufficient to prevent passage of most sperm through the filter. Tests $(n=4)$ of this pumping device and the immunofluorescence procedure with known concentrations of sperm $\left(4.6 \times 10^{4}\right.$ to $8.9 \times 10^{5}$ sperm $\mathrm{l}^{-1}$ ) in seawater over flow speeds from 0.2 to $4.01 \mathrm{~min}^{-1}$ demonstrated an $80 \%$ accuracy in determination of sperm concentrations with the procedures used here. Samples were acquired from each of the 6 collection areas site ${ }^{-1}$ at 30 min intervals by pumping water through the canisters for $5 \mathrm{~min}$ at $1.9 \mathrm{l}$ $\min ^{-1}$ and immediately fixing $120 \mathrm{ml}$ of the retained volume to a final concentration of $2 \%$ formaldehyde (Electron Microscopy Sciences, Fort Washington, PA) and $0.2 \%$ glutaraldehyde (Electron Microscopy Sciences). Samples at each pump site were thus acquired sequentially, requiring a total of about $25 \mathrm{~min}$ for each collection cycle. The start of the collections was timed by when each vertical tube went underwater with the rising tide, so collection times within the 2 pump areas were offset. Data are presented as a mean (SE) of $n=6$ 


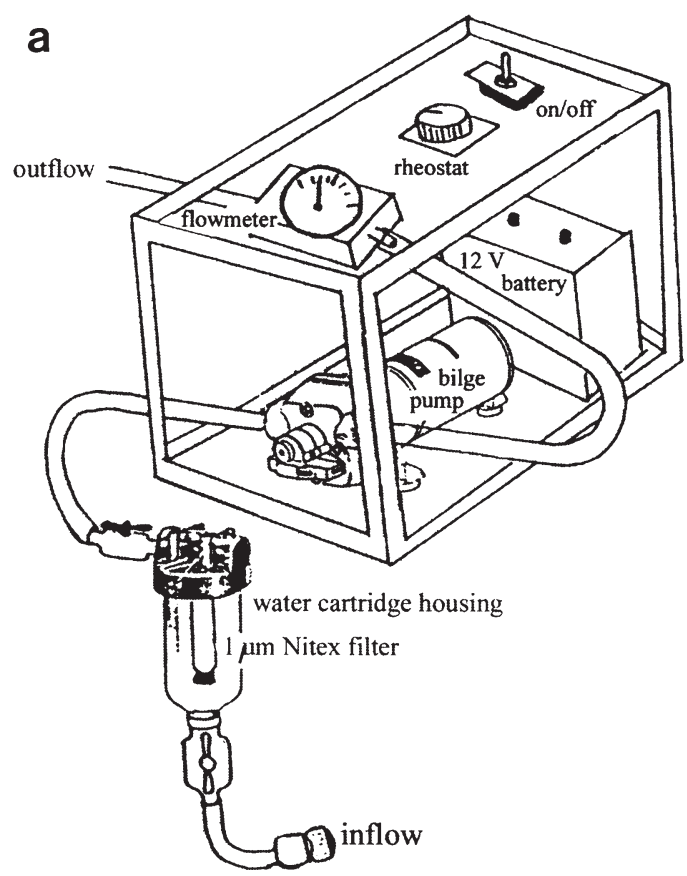

b

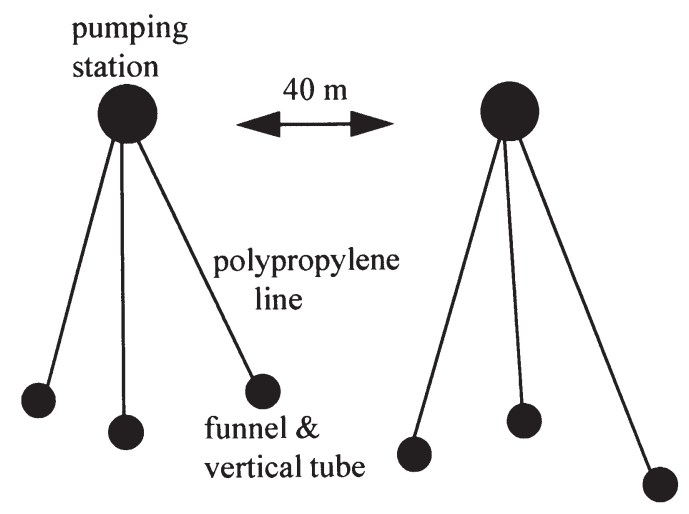

Fig. 1. (a) Apparatus used to collect gamete samples, modified from Mundy et al. (1994). The perforated and stoppered piece of PVC pipe was wrapped $2 \times$ with $1 \mu \mathrm{m}$ Nitex to retain gametes in the cartridge housing. (b) Samples were collected from 6 replicate areas that were located 30 to $40 \mathrm{~m}$ seaward of each pumping station in the mid-intertidal zone

collection sites per 30 min interval throughout the time during which samples could be collected (funnels underwater). During the first and last 30 min intervals of the tidal cycle, $\mathrm{n}=2$ to 4 samples. The sampling scheme used was advantageous in terms of its effective continuous sampling of the water column during the tidal cycle. Between collections, lines were cleared of any residual sample from the previous time point by pre-pumping for $1 \mathrm{~min}$, pouring that sample out, and rinsing the filter prior to collecting the new sample. During the first and last collections in each tidal cycle, the vertical lift capacity of the Flojet ${ }^{\mathrm{TM}}$ pump was nearly exceeded, and a slower pumping speed had to be used, which resulted in a smaller volume of sample being collected. Both the field and laboratory pumping and concentration procedures were tested on unfertilized eggs to assure that these would not be ruptured by the collection methods.

Environmental monitoring. Relative water motion was determined at the Pemaquid Point site using 2 clod cards (Thompson \& Glenn 1994) per collection site to provide an average weight loss $\mathrm{h}^{-1}$ during each tidal cycle. At the Narraguagus, which was a predictably calmer site, 2 current meters (Model 511, MarshMcBirney Inc., Frederick, MD) were deployed to measure current velocity. Photon flux density was measured in the air at an unshaded position on the shore with a Skye quantum sensor (Model 385233, Skye
Instruments Ltd, Wales, UK) and underwater at the Narraguagus at a position between the 6 collection areas and at the height of the submerged fucoids with an Underwater Quantum Sensor (Model LI-192SA, LiCor, Inc., Lincoln, NE). Additional hourly data (1982 to 2000) for wind direction, wind speed, and wave height (Buoy\#44007,www.ndbc.noaa.gov/station_page.phtml? station $=44007 ; 22 \mathrm{~km} \mathrm{SE}$ of Portland, ME, and $55 \mathrm{~km}$ SW of Pemaquid Point) and percent possible daily sunshine for Portland (or Gray), ME (72 km WSW of Pemaquid Point, http://205.156.54.206/er/gyx/ climate.shtml; Northeast Regional Climate Center [nrcc@cornell.edu], Ithaca, NY, supplied 3 h ceiling data) were obtained from the National Oceanic and Atmospheric Administration (NOAA, USA). These sites are near enough to our Pemaquid Point field site to be of value in modelling long-term environmental effects upon reproduction. The model developed in the 'Discussion' has a few small gaps where instrumentation failed on buoy 44007 (i.e., '?' in Table 4). The model was applied to environmental data by averaging each day's data (1982 to 2000) over the period of the daytime high tide and determining whether that day fell within either of the 2 mean bounding states of the model. Salinity was measured during the tidal cycles at the Narraguagus by analyzing samples $(n=2$, 1 per pumping location) of water collected along with gametes every 30 min using a Guildline 8410 A Por- 
tasal Salinometer (Ocean Science Int., Petersfield, UK). Statistical analyses were performed using Systat v.9.0 (SPSS, Inc., Chicago, IL)

Timing and occurrence of fertilization. Pronuclear position within each fixed egg $(n=25$ eggs assayed per concentrate [at all time points where this was possible]) was used to determine the time of fertilization as described by Brawley (1992) and Pearson \& Brawley (1996); measurements were made only on eggs where the sperm and egg pronuclei were in the same focal plane. Appropriate calibration curves were constructed from laboratory fertilizations done at each of the applicable temperatures $\left(12^{\circ} \mathrm{C}\right.$ in October; $8^{\circ} \mathrm{C}$ in November) needed following successful collection of gametes from the field. The presence of a sperm pronucleus in an egg was used as a direct assay of fertilization in all collected eggs, which were tranferred to acetic ethanol (1:3) from each concentrated (aldehyde fixative) sample following quantification, and stained with Wittmann's stain (Wittmann 1965, Brawley 1992, Pearson \& Brawley 1996). Fertilized eggs still enveloped in the oogonial sheath, however, could not be assayed with this technique because of the deeper staining caused by primary aldehyde fixation. An indirect estimate of fertilization of eggs within oogonia was possible though, due to cell wall formation, which begins at fertilization. Fertilized eggs within the oogonium plasmolyzed in the fixative as a result of this nascent cell wall, whereas unfertilized eggs did not.

\section{RESULTS}

The monoclonal antibodies developed for this work strongly labeled the sperm of Fucus vesiculosus, especially the rows of 'hairs' (mastigonemes) along the anterior flagellum, which appeared as a thick structure because of this staining pattern (Fig. 2). The cell body and the anterior flagellum of sperm of $F$. spiralis were weakly stained; sperm of F. evanescens (Fig. 2c) and $A$. nodosum (not shown) were unstained. All of the fucoid sperm collected in the field were labeled in indirect immunofluorescence as the sperm shown in Fig. 2a; thus, our data pertain to F. vesiculosus.

Gamete release occurred on calmer days (Pemaquid, Figs 3 to 5) or during calm periods (Narraguagus, Fig. 6) of the tidal cycle. October 8 was a particularly calm day (Fig. 3, Table 1). The $2 \mathrm{~d}$ when gamete release occurred at Pemaquid (Fig. 3) were sunny (Table 1) with surface photon flux densities (PFD) between 600 and $1200 \mu \mathrm{mol}$ photons $\mathrm{m}^{-2} \mathrm{~s}^{-1}$ at the site during gamete release. No gametes were present in any sample collected at Pemaquid on 25 October, 9 and 24 November or 17 April, although receptacles contained mature gametes on each of these days (i.e., that were not released). Two of

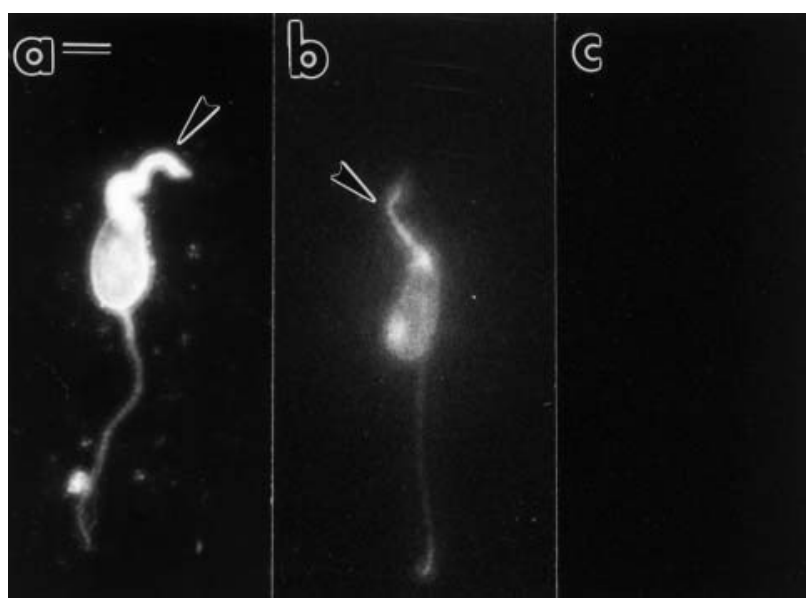

Fig. 2. Labeling of sperm of (a) Fucus vesiculosus, (b) F. spiralis, and (c) F. evanescens (unlabelled) from the Maine shore with monoclonal antibody 144.6 followed by FITC-anti-mouse serum. Note the heavy labeling of the mastigonemes on the anterior flagellum (arrow) in $F$. vesiculosus compared to F. spiralis. Scale bar $=2 \mu \mathrm{m}$

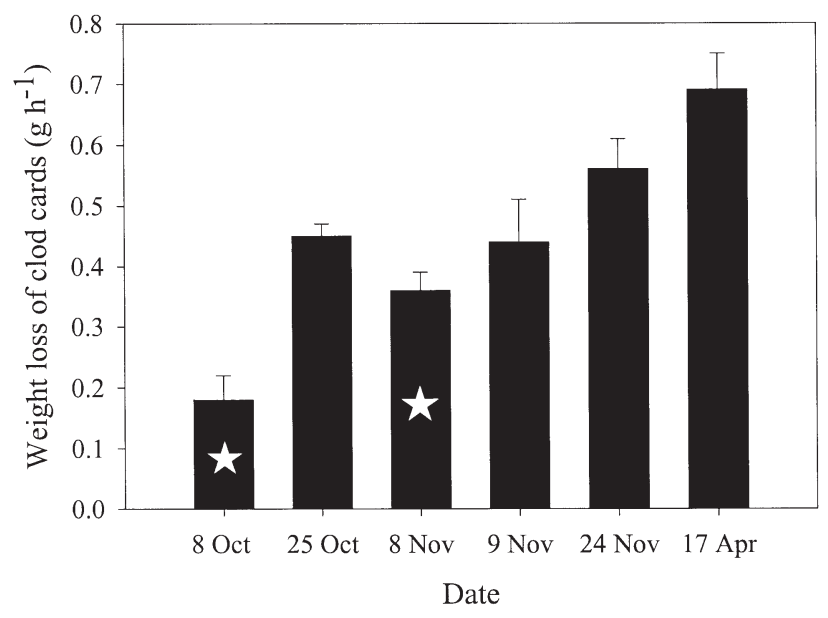

Fig. 3. Weight loss of clod cards (mean $\pm \mathrm{SE}$ ) during the tidal cycle at Pemaquid Point on dates (fall 1999; spring 2000) when samples were taken from the water column. Star on bar

indicates that gamete release occurred on that date

these days (25 October, 17 April) were sunny, but not calm (Fig. 3). Surface PFD was between 1600 and $1700 \mu \mathrm{mol}$ photons $\mathrm{m}^{-2} \mathrm{~s}^{-1}$ at the Narraguagus site during gamete release, and between 100 and $200 \mu \mathrm{mol}$ photons $\mathrm{m}^{-2} \mathrm{~s}^{-1}$ (Fig. 6) at the level of the receptacles in the submerged fucoid bed. A similar temporal pattern of gamete release occurred in the Narraguagus on 1 July 2000 (data not shown) but gamete release was barely detected due to the low numbers of sperm and eggs that were released on that day.

Oogonia were collected from the water column at Pemaquid on 8 October and 8 November $\sim 30$ min prior 


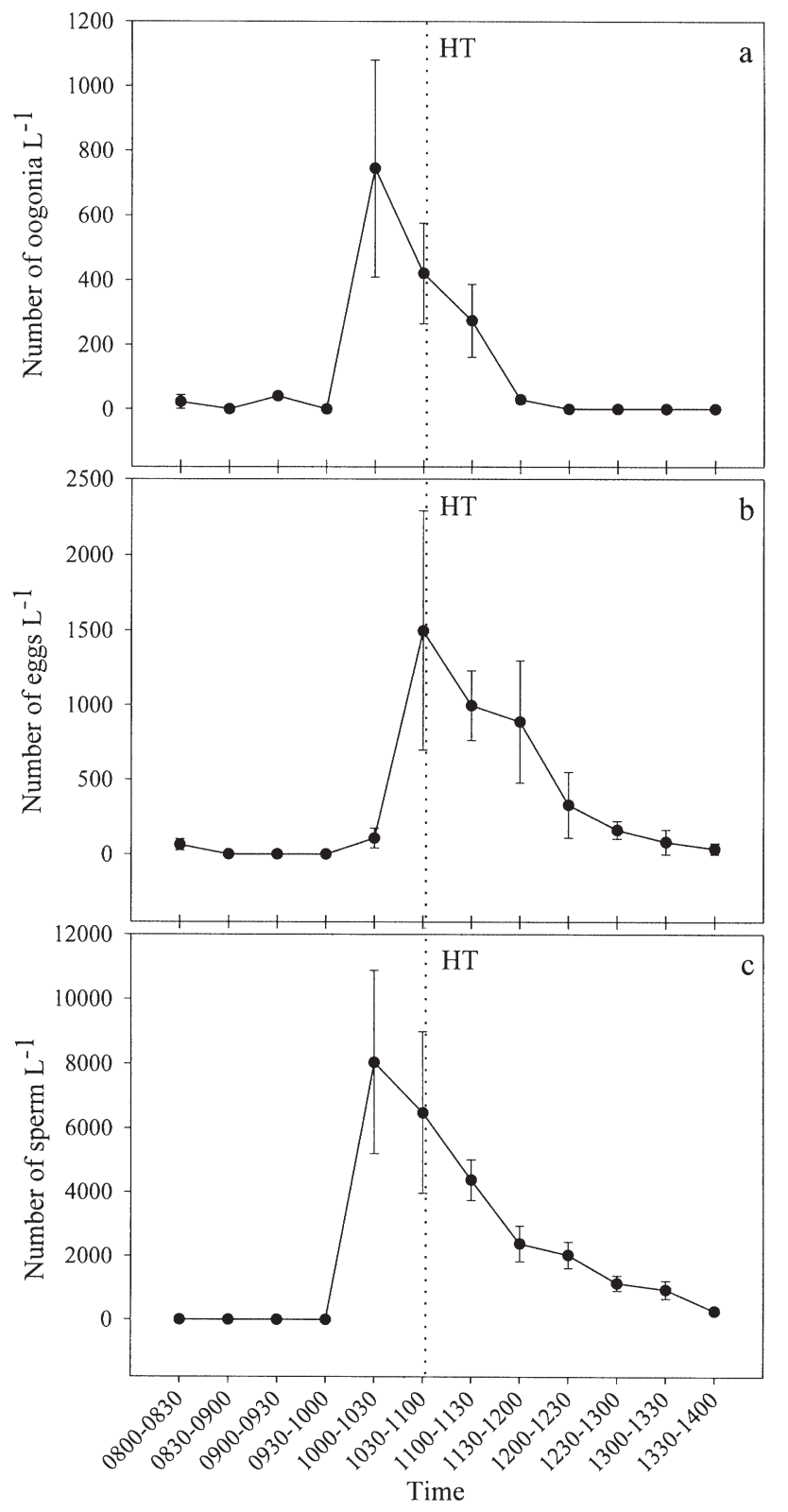

Fig. 4. Concentration (mean \pm SE) (a) of oogonia, (b) eggs, and (c) sperm in water samples collected at $0.5 \mathrm{~h}$ intervals throughout the tidal cycle at Pemaquid Point on 8 October 1999. The time of estimated high tide is marked (HT) with a broken line. Time given on the $x$-axis represents the full period during which algae were covered by seawater

to large numbers of eggs being present (Figs 4 \& 5). A small number of oogonia was collected as algae were first covered by the tide on 8 November but ca $2 \mathrm{~h}$ (8 November) to $2.5 \mathrm{~h}$ (8 October) passed prior to any substantial gamete release, which occurred close to estimated high tide (Figs 4 \& 5). Substantial numbers of gametes remained in the water column for about $2 \mathrm{~h}$ following initial gamete release. Gamete release at the Narraguagus site (2 July 2000) also occurred following

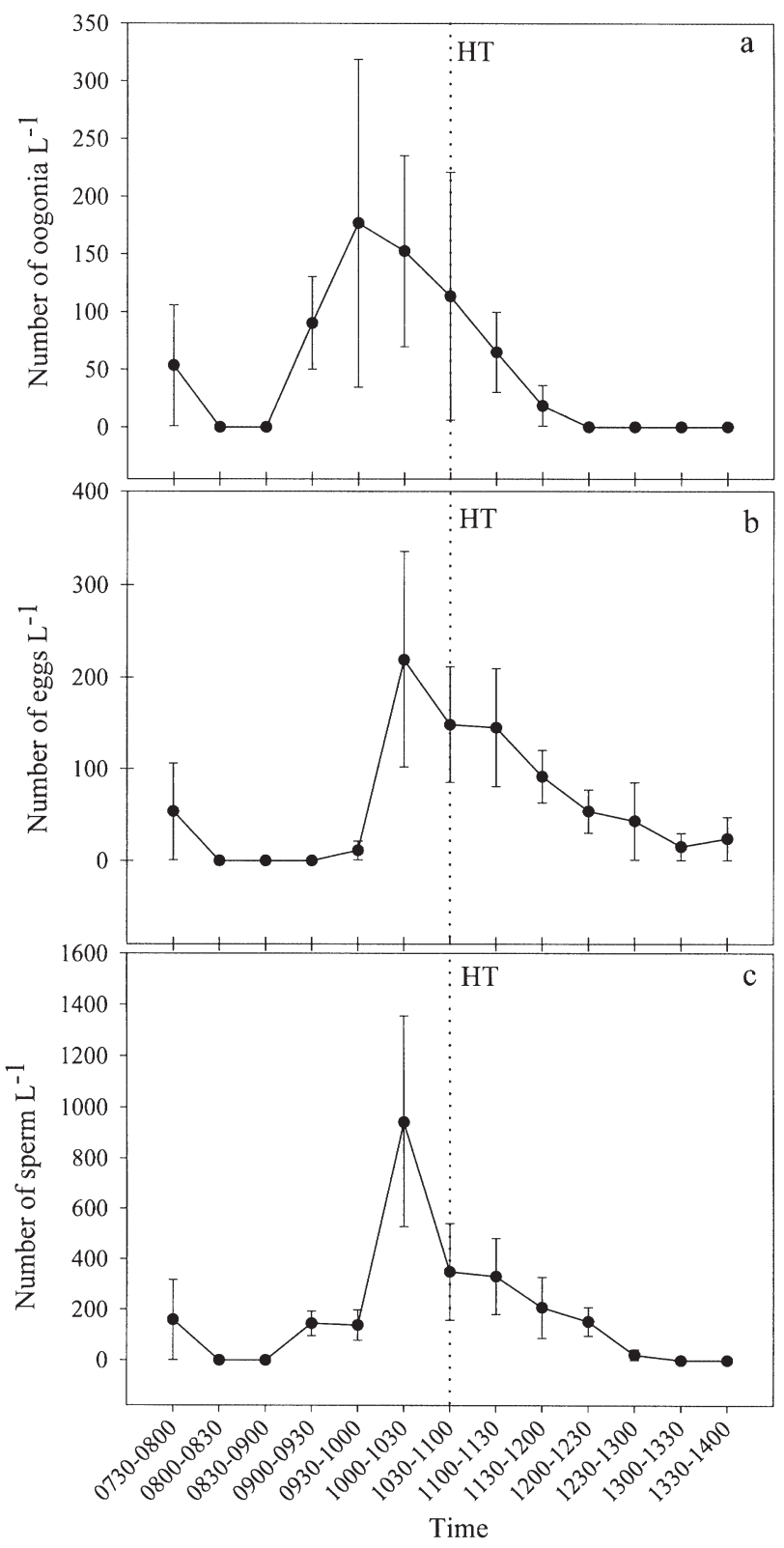

Fig. 5. Concentration (mean $\pm \mathrm{SE}$ ) of (a) oogonia, (b) eggs, and (c) sperm in water samples collected at $0.5 \mathrm{~h}$ intervals throughout the tidal cycle at Pemaquid Point on 8 November 1999. HT and $x$-axis as in Fig. 4

$\sim 3 \mathrm{~h}$ of submergence and began as water velocity diminished near slack high tide (Fig. 6). Salinity on 2 July 2000 was $7.9 \pm 0.5$ psu $(n=2)$ initially, but rose to $17.6 \pm 2.6 \mathrm{psu}(\mathrm{n}=2)$ within $30 \mathrm{~min}$ after algae were covered, and was above 20 psu from 1 to $5 \mathrm{~h}$ of the tidal cycle. The peak salinity of $28.6 \pm 0$ psu $(n=2)$ occurred when algae had been covered by the incoming tide for $2.5 \mathrm{~h}$. Oogonia were collected at the Narraguagus only in the first sample that contained gametes (near high 


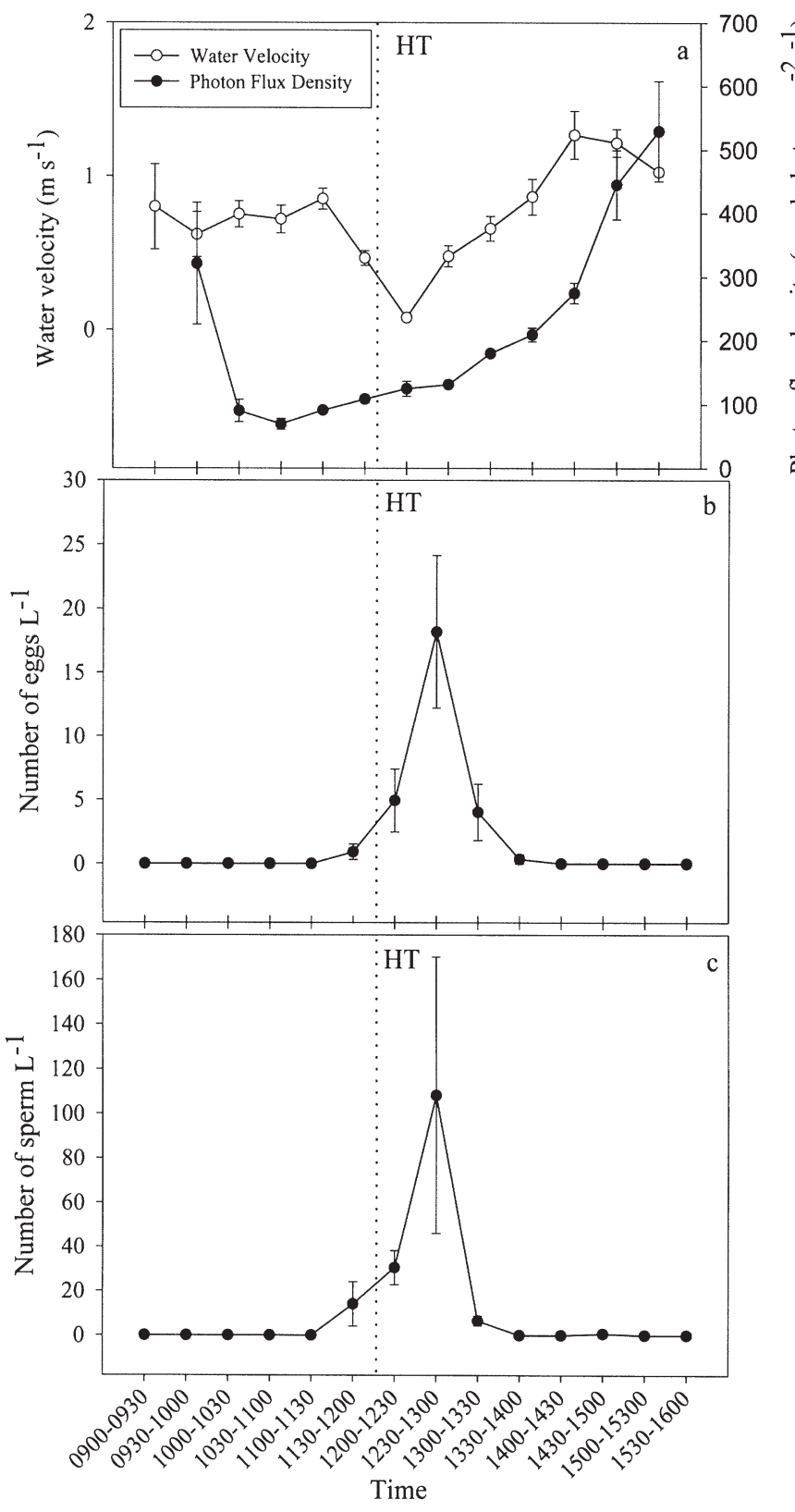

Fig. 6. (a) Environmental parameters, and concentration (mean \pm SE) of (b) eggs and (c) sperm in water samples collected at $0.5 \mathrm{~h}$ intervals throughout the tidal cycle in the Narraguagus River estuary on 2 July 2000. Water velocity was measured with Marsh-McBirney current meters and photon flux density underwater in the fucoid bed was measured with a Li-Cor Underwater Quantum Sensor. Salinity was $\geq 18$ psu between 09:30 and 16:00 h. HT and $x$-axis as in Fig. 4

tide), whereas a few oogonia were collected in sequential samples at Pemaquid for nearly $2 \mathrm{~h}$ following their first appearance.

Sperm and egg release was nearly simultaneous. Large spatial variations in gamete concentrations were
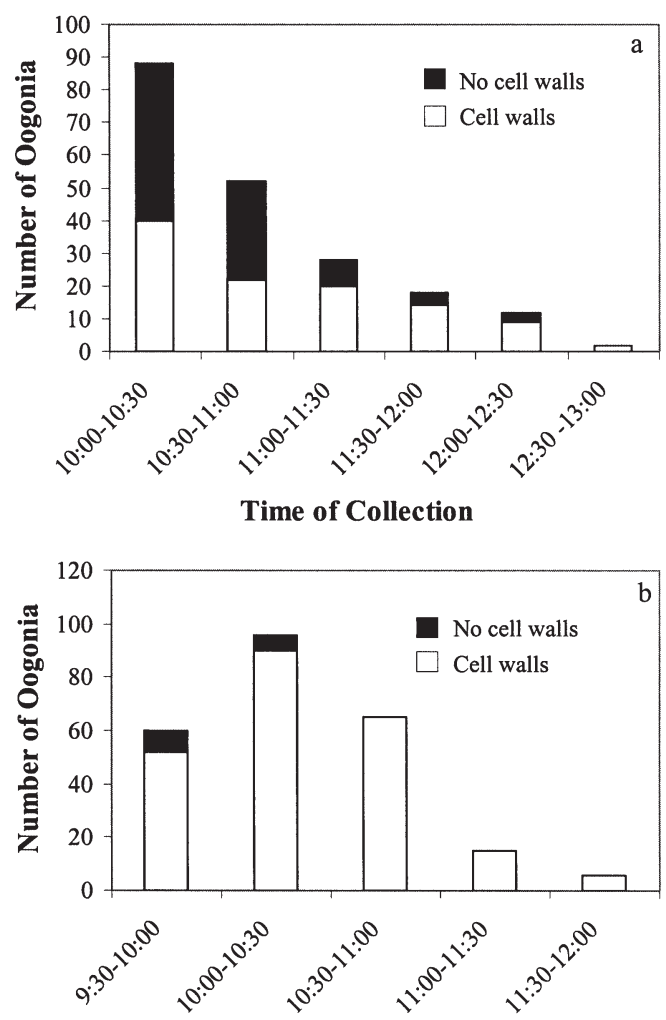

Time of Collection

Fig. 7. Number of oogonia (pooled across replicates) on (a) 8 October and (b) 8 November 1999 at Pemaquid Point that contained eggs that had been fertilized while still contained within the oogonium, as indicated by the presence of a cell wall around 1 to 8 of the eggs in each oogonium

found across the field sites for ca 0.5 to $1 \mathrm{~h}$ following gamete release (note error bars, Figs 4 to 6). However, concentrations of sperm, eggs, and oogonia decreased steadily from the peak concentrations found near high tide, as indicated by the significant negative relationships between concentrations of sperm, eggs, or oogonia, and the elapsed time following the peak mean concentrations near high tide (Table 2). We monitored the field site at Pemaquid Point carefully throughout late September to mid-December 1999 and first observed gamete release at low tide on 9 December 1999. This followed 25 straight days of overcast and stormy weather, including 24 November, when no gametes were collected on a spring high tide.

Analysis of eggs from field samples demonstrated $100 \pm 0 \%$ fertilization success on 8 October, 8 November, and 2 July (1 July eggs were not analyzed due to the small gamete release on this day). Sperm appeared to fertilize some eggs while they were still partially enveloped by the oogonial sheath (Fig. 7). No polyspermic eggs were observed at either the Pemaquid or Narraguagus sites. Eggs were fertilized close to the 
Table 1. Environmental conditions at NOAA Buoy $44007\left(43^{\circ} 31^{\prime} 53^{\prime \prime} \mathrm{N}\right.$, $\left.70^{\circ} 08^{\prime} 39^{\prime \prime} \mathrm{W}\right)$ during sampling period at Pemaquid Point, ME $\left(43^{\circ} 50^{\prime} 8^{\prime \prime} \mathrm{N}\right.$, $69^{\circ} 30^{\prime} 29^{\prime \prime} \mathrm{W}$ ), and daily sunshine (\% of possible) determined by the National Weather Service (NOAA) for Portland, ME

\begin{tabular}{|c|c|c|c|c|}
\hline Date & $\begin{array}{l}\text { Avg wind direction } \\
\left({ }^{\circ} \text { from } N\right)\end{array}$ & $\begin{array}{c}\text { Avg wind } \\
\text { speed }\left(\mathrm{m} \mathrm{s}^{-1}\right)\end{array}$ & $\begin{array}{l}\text { Avg wave } \\
\text { height (m) }\end{array}$ & $\begin{array}{c}\text { Daily } \\
\text { sunshine (\%) }\end{array}$ \\
\hline 8 Oct $1999^{a}$ & 312 (NW) & 2.3 & 0.21 & 90 \\
\hline 25 Oct 1999 & $280(\mathrm{~W})$ & 6.1 & 0.80 & 86 \\
\hline 8 Nov $1999^{a}$ & 322 (NW) & 9.7 & 0.49 & 89 \\
\hline 9 Nov 1999 & 208 (SW) & 3.2 & 0.29 & 4 \\
\hline 24 Nov 1999 & 148 (SE) & 4.4 & 0.90 & 0 \\
\hline 17 Apr 2000 & $025(\mathrm{~N})$ & 8.1 & 1.05 & 77 \\
\hline
\end{tabular}

Table 2. Regression analysis of concentrations of sperm, eggs, and oogonia with elapsed time from the apparent peak abundance of each variable through the end of the tidal cycle (or the time at which concentrations of the dependent variable reached zero; see Figs $4 \& 5$ )

\begin{tabular}{|lrrrrrrc|}
\hline Variable & $\mathrm{n}$ & Intercept & Slope & $\mathrm{r}^{2}$ & $F$ & $\mathrm{df}$ & $\mathrm{p}$ \\
\hline October 8 & & & & & & & \\
Oogonia & 25 & 4353.58 & -369.43 & 0.40 & 15.457 & 1,23 & 0.0007 \\
Eggs & 37 & 6603.46 & -503.79 & 0.31 & 15.673 & 1,35 & 0.0004 \\
Sperm & 41 & 28721.04 & -2175.69 & 0.46 & 33.181 & 1,39 & 0.0000 \\
November 8 & & & & & & & \\
Oogonia & 34 & 905.51 & -76.12 & 0.31 & 14.366 & 1,32 & 0.0006 \\
Eggs & 44 & 759.59 & -56.85 & 0.23 & 12.872 & 1,42 & 0.0009 \\
Sperm & 39 & 3228.02 & -255.95 & 0.29 & 15.064 & 1,37 & 0.0004 \\
\hline
\end{tabular}

time of their release from the receptacle (Fig. 8), as inferred by the calibration made possible by sperm pronuclear position in the egg. In collections made near the time of initial gamete release during the tidal cycle, the sperm pronucleus was found in the outer cortex; in later collections, the sperm pronucleus was deeper within the egg cytoplasm and was found adjacent to the egg pronucleus in the latest collections at Pemaquid. A formal calibration of fertilization timing on 2 July 2000 at the Narraguagus was not required because eggs were collected only over a $1 \mathrm{~h}$ period at any 1 site. The sperm pronucleus had migrated about 3 to $5 \mu \mathrm{m}$ into the egg in collections made from 12:30 to 13:00 h. These eggs also had a thicker cell wall than eggs collected between 12:00 and 12:30 h. The interval during which fertilization occurred was a short portion of the entire tidal cycle. Sperm:egg ratios at the time of fertilization (site averages $\mathrm{d}^{-1}$ ) were ca 10:1 to $70: 1$ (Fig. 9) and decreased steeply later in the tidal cycle.

\section{DISCUSSION}

Recent studies on the reproductive ecology of marine organisms have debated whether sperm limitation or sperm competition occurs at fertilization (reviewed by Levitan \& Petersen 1995, Yund 2000); however, few direct data on natural gamete concentrations and sperm:egg ratios have been available to answer this question (see Warner et al. [1995] and Marconato \& Shapiro [1996] for data for the reef fishes Thalassoma bifasciatum and Sparisoma radians). The data presented here directly confirm that sperm are not limiting to fertilization in Fucus vesiculosus, as suggested by the high levels of natural fertilization found in fucoids (Brawley 1992, Pearson \& Brawley 1996, Serrão et al. 1996, this study) from a wide variety of habitats and global localities. The sperm:egg ratios found naturally in the water column are interesting because such ratios (10:1 to 70:1) have been documented in the laboratory to be ones where high levels of monospermic fertilization occur in F. vesiculosus (Brawley 1990, 1991). Polyspermy, which is lethal, has been demonstrated to increase in fucoid algae under brackish conditions (Brawley 1992, Serrão et al. 1999), possibly because of failure of the sodium-dependent fast block against polyspermy, but in normal seawater the sperm:egg ratios documented here should provide for both high fertilization success and an absence of polyspermy. A number of other taxa (see 'Introduction') have high natural fertilization success. This suggests that sperm competition is more common than sperm limitation, and methodology similar to that applied here can be used in studies of other organisms under natural conditions to further evaluate this important point.

The mode by which gametes are collected from the water column in studies such as these is important, because a potentially severe artifact is fertilization of eggs by sperm in the collection vessel or bag prior to fixation. Our ability to determine when eggs were fertilized eliminated this concern in this study. When fertilization has just occurred, the sperm pronucleus is found in the outer egg cytoplasm, adjacent to the plasma membrane (Brawley \& Quatrano 1979, Brawley 1992, Pearson \& Brawley 1996). After $\sim 10 \mathrm{~min}$ at the temperatures and salinities experienced during this work, the sperm pronucleus begins to migrate through the egg cytoplasm toward the centrally located egg pronucleus. Cell wall formation begins at fertilization. An egg with a sperm pronucleus in the outer cortex 


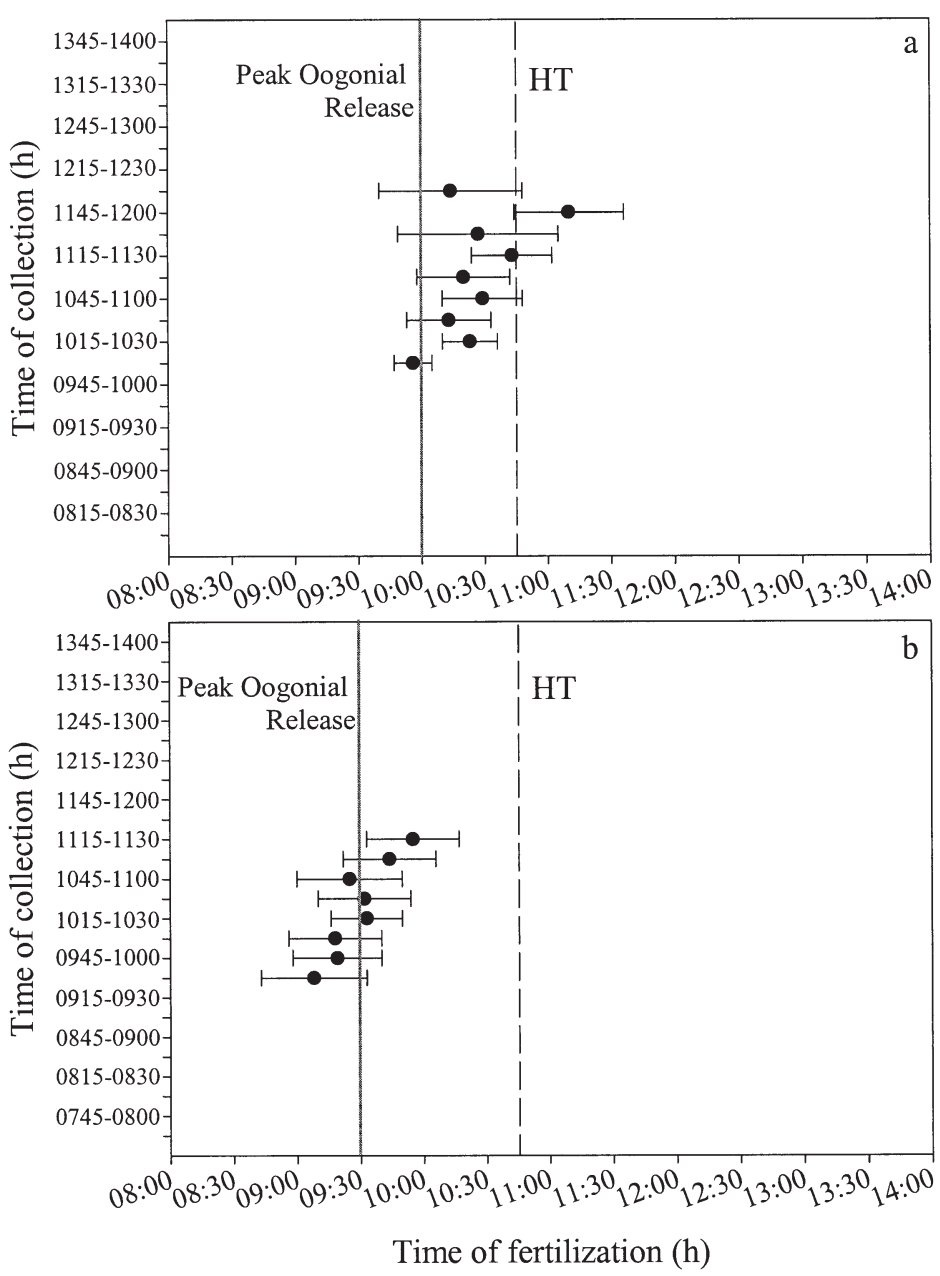

Fig. 8. Time (mean \pm SE) of fertilization of Fucus vesiculosus eggs collected at Pemaquid Point on (a) 8 October and (b) 9 November 1999. The $x$-axis gives the full period during which algae were underwater. The solid line marks the time of peak oogonial release, and the broken line is the time of estimated high tide at the site

could therefore have been fertilized in the water column a few minutes before collection, or in the 1 to 6 min between its collection from the water column and fixation of the concentrated sample. The first batch of eggs collected from the water column had sperm in the outer cortex and cell wall material was minimal; however, at subsequent collection times, the sperm pronucleus was found successively deeper in the egg, which had a thickening cell wall, and calibration of the time of fertilization showed that fertilization was occurring within a very narrow period of the entire tidal cycle. This eliminated the need to remove the first set of egg collections from our analysis to control for a possible collection artifact.

The short interval over which eggs were collected in the Narraguagus estuary probably reflects the strong current found with the outgoing tide, combined with

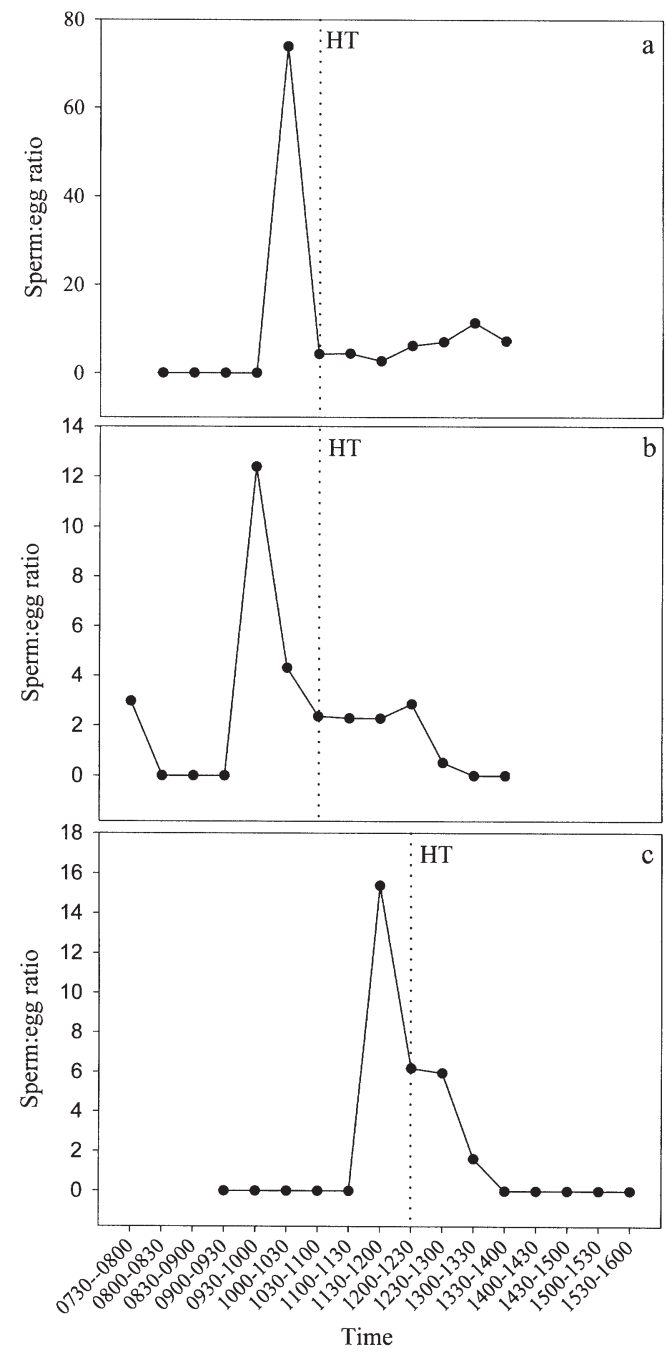

Fig. 9. Sperm:egg ratios throughout the tidal cycle at Pemaquid Point on 8 October (a) and 9 November (b) 1999 and in the Narraguagus River estuary on 2 July 2000 (c); dates are when gamete release was observed. The broken line represents estimated HT

the absence of any fucoid populations above the site we sampled. The window during which gamete release and fertilization can occur is much more limited during the estuarine tidal cycle, compared to calm days on the outer coast, by the strong inward and outward flow of the tide in the estuary. Release of gametes from estuarine populations near slack high tide in Fucus vesiculosus, as in F. ceranoides (Brawley 1992), not only provides calm(er) conditions but also high salinities. At the natural sperm:egg ratios determined here, and salinities above $20 \mathrm{psu}$, no more than $2 \%$ polyspermy is expected in F. vesiculosus based upon laboratory studies (Brawley 1990). In contrast to studies of F. ceranoides (Brawley 1992), however, gamete release by $F$. vesiculosus in the Narraguagus estuary 
does not appear to be tightly regulated by salinity, because salinity rises rapidly and is $>25 \mathrm{psu}$ in this estuary $1.5 \mathrm{~h}$ after algae are covered by the incoming tide. Gamete release occurred much later in the tidal cycle, and was temporally related to diminished water velocity (Fig. 6). Salinity may be a more important factor in temporal regulation of gamete release in $F$. vesiculosus at sites in larger estuaries where salinity remains low for much of the tidal cycle; however, the reproductive success of this species in the Baltic Sea at 3.9 to $6.5 \mathrm{psu}$ is also notable (Serrão et al. 1996, 1999).

The general conditions under which gamete release occurred during this study confirm previous findings (Pearson \& Brawley 1996, Serrão et al. 1996) that 2 conditions are required for gamete release in fucoids: (1) a sunny day and (2) calm conditions. This is due to the relationship between photosynthetic metabolism and gamete release (Pearson \& Brawley 1998, Pearson et al. 1998). Gamete release did not occur during high tide at Pemaquid Point when either of these 2 conditions was absent (Fig. 3, Table 1). We were surprised to find gamete release on 8 November 1999 because conditions were not 'calm', although waves were smaller than on every other day we collected at Pemaquid Point (authors' pers. obs., Fig. 3). Hydrodynamic conditions were likely at 'threshold' for gamete release on 8 November (Fig. 3), but the sunny day supported photosynthesis and the wind direction $(\mathrm{N})$ meant that the area of shoreline we studied was more sheltered than conditions at buoy 44007 (Table 1). Even mild southerly winds usually produce levels of water motion at the Pemaquid field site that should be inhibitory to gamete release (M.L.B. \& S.H.B. pers. obs.). For example, the southerly wind on 9 November produced waves and a relatively high weight loss from clod cards at our field site (Fig. 3), but the wave height on that day at buoy 44007 was similar to that of 8 October (NW wind, Table 1) when conditions at our field site were calm. A prediction of our work is that fucoids on different sides of features such as Pemaquid Point would sometimes reproduce on different days due to their varying exposure, which can cause algae on one side of a point on a given day to be sheltered, while strong wave action is experienced by algae on the other side of the point.

It may be years before a multivariate regression model for fucoid gamete release can be derived for exposed shores in the context of natural environmental conditions. This is due to the difficulty in establishing the threshold conditions that prevent gamete release under natural conditions due to both equipment damage on rough days and the small number of days with irradiance and hydrodynamic conditions near to, but below, the true threshold. As indicated by the preceding discussion, however, we have adequate informa- tion to establish a preliminary model (Table 3) based on bounding conditions at buoy 44007 (i.e., wave height, wind speed and direction) on sunny days that should predict gamete release at our field site. Using the mean conditions of 8 October (best) and 8 November (threshold) as mean bounding conditions, a preliminary model for reproduction from 1982 to 2000 (Table 3) finds that days as calm as 8 October are rare. September is the most favorable month, with a mean of ca $5 \mathrm{~d}$ and a range of 1 to 11 possible days (Table 3) for gamete release during September in different years (single-factor ANOVA [mo], $F_{6,120}=4.057, \mathrm{p}=0.001$; Tukey multiple comparison tests, $\mathrm{p}=0.009$ for September vs April [October vs April was not significant so no other comparisons were made]). Note that buoy 44007 reports hourly means for the variables of interest, but these will generally be of higher magnitude at the buoy than at our more sheltered site at Pemaquid Point, as discussed above. Thus, the sea on 8 October 1999 was smooth and mirror-like at our study site (Force 0 on a Beaufort scale: White 1999, p. 249), but small waves (mean wave height $0.21 \mathrm{~m}$, Table 1) were present at buoy 44007; 8 November 1999 had small wavelets, some breaking (Force 3), at our study site but larger waves were present offshore (mean wave height $0.49 \mathrm{~m}$, Table 1).

Our field data and preliminary model suggest an explanation for the conflicting observations (reviewed by Brawley et al. 1999) of intertidal biologists as to whether gamete release in fucoids occurs during high tide or at low tide as receptacles desiccate. In the tidal cycles we examined at Pemaquid Point and at the Narraguagus, gamete release occurred following several hours of reimmersion of adults, which fits our general finding that a period of photosynthesis is required to potentiate fucoid receptacles for gamete release (Pearson \& Brawley 1996, Pearson et al. 1998). Nevertheless, many intertidal biologists have observed the release of gametes by fucoids at low tide (Brawley et al. 1999). We believe that we can explain these conflicting observations with data from our Pemaquid Point field site in 1999, where gamete release at low tide (9 December) was not observed until a prolonged period of stormy, overcast weather had occurred. Our local monitoring and reference to conditions at buoy 44007 suggest that the last date favorable for gamete release at our field site was 12 November 1999. Successive days during the neap cycle were stormy, and this weather pattern continued through the following spring tide series. Gametangia mature in sequential batches every $2 \mathrm{wk}$ within the conceptacles of fucoid receptacles, and this occurs on spring tides centered around full and new moons in Fucus vesiculosus. We hypothesize that release of gametangia at low tide begins when their release near high tide has been inhibited for several 
Table 3. Model (I) and predictions (II) of model for Fucus vesiculosus gamete release during the reproductive seasons ${ }^{\mathrm{a}}$ of 1982 to 2000 on the west side of Pemaquid Point, ME

I. Model with 2 states (A and B) of mean conditions at nearby monitoring stations at Portland (National Weather Service, sunshine) and Buoy 44007, 22 $\mathrm{km}$ SE of Portland (National Data Buoy Center, all other conditions) that predict gamete release at field site. States are based on conditions at monitoring stations on days of field work in 1999/2000 (see Table 1); wave height usually lower at Pemaquid Point than stated bounding conditions at buoy 44007

\begin{tabular}{lcccc} 
& $\begin{array}{c}\text { Sunshine } \\
(\% \text { possible }\end{array}$ & $\begin{array}{c}\text { Wave } \\
\text { height }(\mathrm{m})\end{array}$ & $\begin{array}{c}\text { Wind direc- } \\
\text { tion }\left({ }^{\circ}\right)\end{array}$ & $\begin{array}{c}\text { Wind speed } \\
\left(\mathrm{m} \mathrm{s}^{-1}\right)\end{array}$ \\
\hline (A) Best days & $75-100$ & $\leq 0.3$ & $270 \rightarrow 0 \rightarrow 90$ & $\leq 2.0$ \\
(B) Other possible days & $75-100$ & $0.3-0.5$ & $270 \rightarrow 0 \rightarrow 90$ & $2.0-10.0$
\end{tabular}

II. Predicted mean number of days $\left( \pm\right.$ SE) each mo $\left(1982\right.$ to $\left.2000^{\circ}\right)$ for gamete release by Fucus vesiculosus on west side of Pemaquid Point

\begin{tabular}{lccc} 
& Best days & Other days & $\begin{array}{c}\text { Monthly range (1982 to 2000) of all } \\
\text { possible days for gamete release }\end{array}$ \\
\hline Mar & $0.21 \pm 0.10$ & $2.53 \pm 0.45$ & $0-9$ \\
Apr $^{\mathrm{d}}$ & $0.29 \pm 0.14$ & $2.06 \pm 0.37$ & $0-7$ \\
May $^{\mathrm{e}}$ & $0.11 \pm 0.08$ & $2.28 \pm 0.50$ & $0-8$ \\
Sep & $0.63 \pm 0.16$ & $4.00 \pm 0.56$ & $1-11$ \\
Oct & $0.37 \pm 0.16$ & $2.68 \pm 0.38$ & $0-9$ \\
Nov $^{\mathrm{e}}$ & $0.25 \pm 0.19$ & $2.18 \pm 0.31$ & $0-7$ \\
Dec & $0.06 \pm 0.06$ & $1.72 \pm 0.42$ & $0-5$
\end{tabular}

${ }^{\text {a }}$ Receptacles are mature from March to May and September to December on the outer coast of Maine; reproduction in March to early April can only occur in milder winters (e.g., 2000), when ice damage to receptacles is reduced (Speransky et al. 1999)

${ }^{\text {b}}$ In parts of 1995 to 1997 where daily percent sunshine was not calculated by the National Weather Service, $3 \mathrm{~h}$ averages of sky cover were used to determine sunny days on the basis of the NWS's determination of No Ceiling (Clear)

'The model predicts the following total number of days (March to May + September to December) each year for gamete release: 24 (1982), 15 (1983, data missing for November), 29 (1984), 23 (1985), 20 (1986), 18 (1987, data missing for April), 21 (1988), 21 (1989), 14 (1990), 20 (1991), 17 (1992), 14 (1993), 15 (1994), 16 (1995), 21 (1996), 23 (1997, data missing for November), 12 (1998), 18 (1999), 15 (2000, data missing for May)

${ }^{\mathrm{d}} \mathrm{n}=18$ yr due to missing wave height data in 1 year

${ }^{e} \mathrm{n}=17$ yr due to missing wave height data in 2 years

ronmental data predicts that many years (Table 4 ) have periods of 1 mo or more when gamete release at high tide could not occur, which we hypothesize will cause gamete release at low tide. The model predicts that this will be more common in May and late fall than in September (Table 4), which fits our personal observations (1989 to 2000, S.H.B. pers. obs.) on the Maine shore.

Another important consequence of delayed gamete release due to stormy conditions is the potential for hybridization to occur between fucoid species. Bolwell et al. (1977), Edwards et al. (1997) and Edwards (1999) demonstrated that, when ripe receptacles are stored in the laboratory for several days prior to releasing gametes, species-specific barriers breakdown and hybrids can be produced. Our field site was selected deliberately as a place with little cover of other fucoids that would be reproductive simultaneously with Fucus vesiculosus, but many rocky shores of the northern Atlantic have appropriate tidal heights to permit development of broad belts of $F$. spiralis, $F$. vesiculosus, $F$. evanescens and/or $F$. serratus on the same shore. A number of spring tide series (1982 to 2000) lacked even $1 \mathrm{~d}$ when gamete release at high tide could have occurred, according to our model (Table 4). Our field work and inspection of archival data predict that $F$. vesiculosus reproduces most effectively on portions of the Maine shore similar to the western side of Pemaquid Point from September through mid-October, when most spring tide series have at least 1 calm, sunny day (Table 3). At other times, the

weeks by stormy weather and there are too many mature gametangia in the conceptacle. Two semilunar cycles of gamete maturation would have occurred without release at high tide by 9 December 1999, given that sunny, calm(er) conditions are required for gamete release when algae are submerged. Whether substantial fertilization occurs when gametes are released by dioecious fucoids at low tide or whether most gametangia are damaged deserves study because dispersal distance of zygotes could vary substantially under these contrasting conditions (Brawley et al. 1999). Applying our preliminary model (Table 3) to 1982 to 2000 envi- potential for stormy weather to increase the incidence of hybridization could be high, and we observed one such period directly in 1999 (i.e., the second spring tide in October).

The remarkable magnitude of zygote production by fucoids on calm days near full and new moons may have strong effects upon herbivores and detritivores in the shallow coastal areas of the North Atlantic. These calmer days are also available as potential foci for reproduction by other intertidal and shallow subtidal organisms, which should be considered as studies of sperm limitation versus sperm competition in such taxa continue. 
Table 4. Intervals over spring tides ( $\pm 4 \mathrm{~d}$ of full and new moons) where gamete release should have occurred on at least 1 daytime high tide based on the model (Table 3 ). I = spring tide $1 ; \mathrm{II}=$ spring tide 2 ; III = spring tide 3 , which is rarely present; $\mathrm{R}=$ release predicted $; 0=$ no release predicted; $?=$ environmental data incomplete for date; underline: release predicted to be absent throughout indicated period (including neap tide[s])

\begin{tabular}{|c|c|c|c|c|c|c|c|c|c|c|c|c|c|c|c|c|}
\hline \multirow[t]{2}{*}{ Year } & \multicolumn{2}{|c|}{ Mar } & \multicolumn{2}{|c|}{ Apr } & \multicolumn{3}{|c|}{ May } & \multicolumn{2}{|c|}{ Sep } & \multicolumn{2}{|c|}{ Oct } & \multicolumn{2}{|c|}{ Nov } & \multicolumn{3}{|c|}{ Dec } \\
\hline & I & II & I & II & I & II & III & I & II & I & II & I & II & I & II & III \\
\hline 1982 & 0 & 0 & $\mathrm{R}$ & 0 & $\mathrm{R}$ & 0 & & 0 & 0 & $\mathrm{R}$ & $\mathrm{R}$ & 0 & $\mathrm{R}$ & $\mathrm{R}$ & 0 & \\
\hline 1983 & 0 & $\mathrm{R}$ & 0 & $\mathrm{R}$ & 0 & $\mathrm{R}$ & & $\mathrm{R}$ & $\mathrm{R}$ & $\mathrm{R}$ & 0 & $?$ & $?$ & 0 & $\mathrm{R}$ & \\
\hline 1984 & $\mathrm{R}$ & 0 & $\mathrm{R}$ & 0 & $\mathrm{R}$ & 0 & $\mathrm{R}$ & $\mathrm{R}$ & $\mathrm{R}$ & $\mathrm{R}$ & $\mathrm{R}$ & 0 & $?$ & 0 & $?$ & \\
\hline 1985 & $\mathrm{R}$ & $\mathrm{R}$ & 0 & $\mathrm{R}$ & $\mathrm{R}$ & $\mathrm{R}$ & & $\mathrm{R}$ & 0 & $\mathrm{R}$ & $\mathrm{R}$ & $\mathrm{R}$ & 0 & 0 & 0 & \\
\hline 1986 & 0 & $\mathrm{R}$ & 0 & 0 & 0 & $?$ & & $\mathrm{R}$ & $\mathrm{R}$ & $\mathrm{R}$ & 0 & $\mathrm{R}$ & $\mathrm{R}$ & $\mathrm{R}$ & 0 & 0 \\
\hline 1987 & 0 & 0 & $?$ & $?$ & $\mathrm{R}$ & $\mathrm{R}$ & & $\mathrm{R}$ & $\mathrm{R}$ & 0 & 0 & 0 & $\mathrm{R}$ & $\mathrm{R}$ & $\mathrm{R}$ & \\
\hline 1988 & 0 & 0 & $\mathrm{R}$ & 0 & $\mathrm{R}$ & $\mathrm{R}$ & 0 & $\mathrm{R}$ & $\mathrm{R}$ & 0 & $\mathrm{R}$ & $\mathrm{R}$ & $\mathrm{R}$ & 0 & $\mathrm{R}$ & \\
\hline 1989 & $\mathrm{R}$ & 0 & 0 & $\mathrm{R}$ & 0 & 0 & & $\mathrm{R}$ & $\mathrm{R}$ & $\mathrm{R}$ & $\mathrm{R}$ & 0 & 0 & $\mathrm{R}$ & $\mathrm{R}$ & \\
\hline 1990 & $\mathrm{R}$ & $\mathrm{R}$ & $\frac{\mathrm{R}}{\mathrm{R}}$ & $\mathrm{R}$ & 0 & 0 & & $\mathrm{R}$ & $\mathrm{R}$ & 0 & $\mathrm{R}$ & 0 & 0 & $\mathrm{R}$ & 0 & 0 \\
\hline 1991 & 0 & $\mathrm{R}$ & $\mathrm{R}$ & $\mathrm{R}$ & $\mathrm{R}$ & 0 & & $\mathrm{R}$ & $\mathrm{R}$ & 0 & $\mathrm{R}$ & 0 & $\mathrm{R}$ & 0 & $\mathrm{R}$ & \\
\hline 1992 & 0 & $\mathrm{R}$ & 0 & $\mathrm{R}$ & 0 & 0 & 0 & $\mathrm{R}$ & $\mathrm{R}$ & $\mathrm{R}$ & $\mathrm{R}$ & $\mathrm{R}$ & $\mathrm{R}$ & $\mathrm{R}$ & $\mathrm{R}$ & \\
\hline 1993 & 0 & 0 & 0 & 0 & 0 & 0 & & $\mathrm{R}$ & $\mathrm{R}$ & 0 & 0 & $\mathrm{R}$ & $\mathrm{R}$ & 0 & $\mathrm{R}$ & \\
\hline 1994 & 0 & 0 & 0 & 0 & 0 & 0 & & $\mathrm{R}$ & $\mathrm{R}$ & $\mathrm{R}$ & $\mathrm{R}$ & 0 & $\mathrm{R}$ & 0 & 0 & \\
\hline 1995 & $\mathrm{R}$ & $\mathrm{R}$ & $\mathrm{R}$ & $\frac{\mathrm{R}}{\mathrm{R}}$ & 0 & 0 & & 0 & 0 & $\mathrm{R}$ & 0 & $\mathrm{R}$ & 0 & $\mathrm{R}$ & $\mathrm{R}$ & \\
\hline 1996 & $\mathrm{R}$ & $\mathrm{R}$ & $\mathrm{R}$ & 0 & 0 & $\mathrm{R}$ & & $\mathrm{R}$ & $\mathrm{R}$ & $\mathrm{R}$ & $\mathrm{R}$ & 0 & $\mathrm{R}$ & 0 & 0 & \\
\hline 1997 & 0 & $\mathrm{R}$ & $\mathrm{R}$ & $\mathrm{R}$ & 0 & $\mathrm{R}$ & & $\mathrm{R}$ & $\mathrm{R}$ & $\mathrm{R}$ & 0 & $?$ & ? & 0 & 0 & \\
\hline 1998 & 0 & 0 & $\mathrm{R}$ & $\mathrm{R}$ & 0 & $\mathrm{R}$ & & 0 & $\mathrm{R}$ & $\mathrm{R}$ & $\mathrm{R}$ & $\mathrm{R}$ & 0 & 0 & 0 & \\
\hline 1999 & $\mathrm{R}$ & $\mathrm{R}$ & 0 & $\mathrm{R}$ & $\mathrm{R}$ & $\mathrm{R}$ & & 0 & $\mathrm{R}$ & $\mathrm{R}$ & 0 & $\mathrm{R}$ & 0 & 0 & 0 & \\
\hline 2000 & $\mathrm{R}$ & 0 & 0 & $\mathrm{R}$ & $?$ & ? & & $\mathrm{R}$ & 0 & 0 & $\mathrm{R}$ & 0 & $\mathrm{R}$ & $\mathrm{R}$ & $\mathrm{R}$ & \\
\hline
\end{tabular}

Acknowledgements. This work constitutes part of the MS thesis of the senior author at the University of Maine. M.L.B. and S.H.B. are grateful to Ms Amy Wilson, Mr Richard Gordon, and Ms Heidi Crachan for assistance in the field during many cold, wet days; to the staff of the Darling Marine Center (University of Maine); to the Heights for access to their shore along the Narraguagus estuary; and to Mr Tom Tripp of the U.M. Physics Shop for fabrication of part of the pump apparatus. S.H.B. thanks Mr Herbie Munasinghe, who assisted her in preparing the monoclonal antibodies used in this study during a sabbatical visit in J.A.C.'s laboratory (1998), and Dr Joanna Kain Jones, for continued vehicle loans and hospitality at Port St. Mary, Isle of Man. We are grateful for the support of this work by the National Science Foundation (IBN 9604848 to S.H.B.).

\section{LITERATURE CITED}

Babcock RC, Mundy CN (1992) Reproductive biology, spawning and field fertilization rates of Acanthaster planci. Aust J Mar Freshw Res 43:525-534

Babcock RC, Mundy CN, Keesing J, Oliver J (1992) Predictable and unpredictable spawning events: in situ behavioural data from free-spawning coral reef invertebrates. Invertebr Reprod Dev 22:213-228

Babcock RC, Mundy N, Whitehead D (1994) Sperm diffusion models and in situ confirmation of long distance fertilization in the free-spawning asteroid Acanthaster planci. Biol Bull 186:17-28

Berndt ML (2000) The reproductive ecology of Fucus vesiculosus Linnaeus at selected sites on the Maine shore. MS thesis, University of Maine.

Bolwell GP, Callow JA, Callow ME, Evans LV (1977) Crossfertilisation in fucoid seaweeds. Nature 268:626-627

Brawley SH (1990) The polyspermy block in fucoid algae. In: Wiessner W, Robinson DG, Starr RC (eds) Cell walls and surfaces, reproduction, photosynthesis. Springer-Verlag, Berlin, p 134-144

Brawley SH (1991) The fast block against polyspermy in fucoid algae is an electrical block. Dev Biol 144:94-106

Brawley SH (1992) Fertilization in natural populations of the dioecious brown alga Fucus ceranoides and the importance of the polyspermy block. Mar Biol 113:145-157

Brawley SH, Johnson LE (1992) Gametogenesis, gametes and zygotes: ecological perspectives on sexual reproduction in the algae. Br Phycol J 27:233-52

Brawley SH, Quatrano RS (1979) Effects of microtubule inhibitors on pronuclear migration and embryogenesis in Fucus distichus (Phaeophyta). J Phycol 15:266-272

Brawley SH, Johnson LE, Pearson GA, Speransky V, Li R, Serrão E (1999) Gamete release at low tide in fucoid algae: maladaptive or advantageous? Am Zool 39:218-229

Coma R, Lasker HR (1997) Small-scale heterogeneity of fertilization success in a broadcast spawning octacoral. J Exp Mar Biol Ecol 214:107-120

Denny MW, Shibata MF (1989) Consequences of surf-zone turbulence for settlement and external fertilization. Am Nat 134:859-889

Edwards GO (1999) Cross-fertilisation in Fucus: a molecular approach. PhD thesis, University of Birmingham

Edwards GO, Callow JA, Brownlee C (1997) Cross-fertilisation in Fucus: a molecular approach (Abstract). Phycologia $36: 28$

Engel CR, Wattier R, Destombe C, Valero M (1999) Performance of non-motile male gametes in the sea: analysis of paternity and fertilization success in a natural population of a red seaweed, Gracilaria gracilis. Proc R Soc Lond Ser B Biol Sci 266:1879-1886

Fritsch FE (1945) The structure and reproduction of the algae, Vol 2. Cambridge University Press, Cambridge

Galfre G, Milstein C (1981) Preparation of monoclonal antibodies: strategies and procedures. Methods Enzymol $73: 1-46$ 
Giese AC, Kanatani H (1987) Maturation and spawning. In: Giese AC, Pearse JS, Pearse VB (eds) Reproduction of marine invertebrates. Blackwell Scientific, Boxwood Press, Palo Alto/Pacific Grove, CA, p 251-329

Grant CM, Hooker SH, Babcock RC, Creese RG (1998) Sychronous spawning and reproductive incompatibility of 2 bivalve species: Paphies subtriangulata and Paphies australis. Veliger 41:148-156

Jones JL, Callow JA, Green JR (1988) Monoclonal antibodies to sperm surface antigens of the brown alga Fucus serratus exhibit region-, gamete-, species- and genus-preferential binding. Planta 176:298-306

Kaczmarska I, Dowe LL (1997) Reproductive biology of the red alga Polysiphonia lanosa (Ceramiales) in the Bay of Fundy, Canada. Mar Biol 128:695-703

Kiflawi MA, Mazeroll I, Goulet D (1998) Does mass spawning enhance fertilization in coral reef fish? A case study of the brown surgeonfish. Mar Ecol Prog Ser 172:107-114

Lasker HR, Brazeau DA, Calderon J, Coffroth MA, Coma R, Kim K (1996) In situ rates of fertilization among broadcast spawning gorgonian corals. Biol Bull 190:45-55

Levitan DR, Petersen C (1995) Sperm limitation in the sea. Trends Ecol Evol 10:228-231

Levitan DR, Sewell MA, Chia FS (1992) How distribution and abundance influence fertilization success in the sea urchin Strongylocentrotus franciscanus. Ecology 73:248-254

Marconato A, Shapiro DY (1996) Sperm allocation, sperm production and fertilization rates in the bucktooth parrotfish. Anim Behav 52:971-980

Miller PE, Scholin CA (1998) Identification and enumeration of cultured and wild Pseudo-nitzschia (Bacillariophyceae) using species-specific LSU rRNA-targeted fluorescent probes and filter-based whole cell hybridization. J Phycol 34:371-382

Müller DG, Gassmann G (1978) Identification of the sex attractant in the marine brown alga Fucus vesiculosus. Nature 65:389

Mundy C, Babcock R, Ashworth J, Small J (1994) A portable, discrete-sampling submersible plankton pump and its use in sampling starfish eggs. Biol Bull 186:168-171

Oliver J, Babcock R (1992) Aspects of the fertilization ecology of broadcast spawning corals: Sperm dilution effects and in situ measurements of fertilization. Biol Bull 183: 409-417

Pearson GA, Brawley SH (1996) Reproductive ecology of Fucus distichus (Phaeophyceae): an intertidal alga with successful external fertilization. Mar Ecol Prog Ser 143:211-223

Editorial responsibility: Otto Kinne (Editor), Oldendorf/Luhe, Germany
Pearson GA, Brawley SH (1998) A model for signal transduction during gamete release in the fucoid alga Pelvetia compressa. Plant Physiol 118:305-313

Pearson GA, Serrão EA, Brawley SH (1998) Control of gamete release in fucoid algae: Sensing hydrodynamic conditions via carbon acquisition. Ecology 79:1725-1739

Pennington JT (1985) The ecology of fertilization of echinoid eggs: the consequences of sperm dilution, adult aggregation, and synchronous spawning. Biol Bull 169: 417-430

Petersen CW (1991) Variation in fertilization rate in the tropical reef fish Halichoeres bivattatus: correlates and implications. Biol Bull 181:232-237

Petersen CW, Warner RR, Cohen S, Hess HC, Sewell AT (1992) Variable pelagic fertilization success: implications for mate choice and spatial patterns of mating. Ecology 73: 391-401

Serrão EA (1996) Reproductive ecology of Fucus vesiculosus L. in the Baltic Sea. PhD thesis, University of Maine

Serrão EA, Pearson GA, Kautsky L, Brawley SH (1996) Successful external fertilization in turbulent environments. Proc Natl Acad Sci USA 93:5286-5290

Serrão EA, Brawley SH, Hedman J, Kautsky L, Samuelsson G (1999) Reproductive success of Fucus vesiculosus in the Baltic Sea. J Phycol 35:254-269

Sewell MA, Levitan DR (1992) Fertilization success during a natural spawning of the dendrochirote sea cucumber Cucumaria miniata. Bull Mar Sci 51:161-166

Speransky SR, Brawley SH, Halteman WA (2000) Gamete release is increased by calm conditions in the coenocytic green alga Bryopsis (Chlorophyta). J Phycol 36:730-739

Speransky VV, Speransky SR, Brawley SH (1999) Cryoanalytical studies of freezing damage and recovery in Fucus vesiculosus (Phaeophyceae). J Phycol 35:1264-1275

Thompson TL, Glenn EP (1994) Plaster standards to measure water motion. Limnol Oceanogr 39:1768-1779

Warner RR, Shapiro DY, Marcanato A, Petersen CW (1995) Sexual conflict: males with highest mating success convey the lowest fertilization benefits to females. Proc R Soc Lond Ser B Biol Sci 262:135-139

White MJ (1999) Eldridge tide and pilot book 2000. White, White \& White, Boston

Wittmann W (1965) Aceto-iron-haematoxylin-chloral hydrate for chromosome staining. Stain Tech 40:161-164

Yund PO (2000) How severe is sperm limitation in natural populations of marine free-spawners. Trends Ecol Evol 15:10-13

Submitted: February 1, 2001; Accepted: June 7, 2001 Proofs received from author(s): January 3, 2002 